\title{
A Short Review on Ultra-High-Strength Maraging Steels and Future Perspectives
}

\author{
Daniela Passarelo Moura da Fonseca ${ }^{a}$ (1), Ana Larissa Melo Feitosa ${ }^{(1)}$, Leandro Gomes de Carvalho ${ }^{b *}$ (), \\ Ronald Lesley Plaut ${ }^{a}$ (D), Angelo Fernando Padilha ${ }^{a}$ (D) \\ ${ }^{a}$ Universidade de São Paulo, Escola Politécnica, Departamento de Engenharia Metalúrgica e de \\ Materiais, Av. Prof. Mello de Moraes, 2463, CEP 05508-030, São Paulo, SP, Brasil \\ ${ }^{b}$ Centro Universitário Adventista de São Paulo, Estrada de Itapecerica, 5859, CEP 05858-001, São \\ Paulo, SP, Brasil
}

Received: October 11, 2020; Revised: November 17, 2020; Accepted: November 27, 2020

\begin{abstract}
Maraging steels are among the highest strength steels commercially available. Despite being relatively rare and expensive, they may present a yield strength around $3 \mathrm{GPa}$ and are indispensable for various applications. In the present paper, several aspects will be reviewed related to maraging steels including a brief history of its development, microstructure and acting hardening mechanisms, loss of toughness with the tensile strength increase, resistance to oxidation, and corrosion, nitriding behavior, and future perspectives.
\end{abstract}

Keywords: maraging steels, microstructure, mechanical properties, oxidation.

\section{Introduction}

Steels have been the engineering materials most used in the last two centuries and probably will continue being so in the present century. The annual steel production in 2019 has been 1.845 billion tons ${ }^{1}$. This huge production has been due to several factors: large availability of iron ore with high iron content, relative ease of reduction from the ore to the metal (pig iron), availability of advanced fabrication technologies as well as the established ones, the existence of thousands of chemical steel compositions with differentiated properties and geometries that fulfill most complex project requirements, apart from relatively low final prices. As most of the steel applications are structural, the development of the high strength steels has been given special attention in the last decades.

Figure 1 shows the evolution of the yield strength of the structural steels since 1850, according to Albert M. Hall'2, then head of the Ferrous and High Alloy Metallurgy Division, of the Battelle Memorial Institute (Columbus, Ohio, USA). The initial part of the graph presents the steels for massive structural applications. For the special applications, we may pay attention to the change in the slope of the curve at the end of the ' $40 \mathrm{~s}$, associated with the usage of steels in the aeronautical structures. Moreover, it is worth mentioning the foresight of the author (the article was published in 1964), of the steels with yield strength over $400 \mathrm{ksi}$. (2760 MPa), which became a commercial reality only the ' 80 s.

The upper limit for the mechanical strength of a crystalline solid has been theoretically calculated in two ways. The oldest one proposed by Frenkel ${ }^{3}$ in 1926, assumes that there are no crystalline defects (dislocations), and calculates the theoretical shear strength to cause slip between two parallel crystal planes. The second approach, published by Orowan ${ }^{4}$ in 1949 ,

*e-mail: leandro.carvalho@alumni.usp.br estimates that the stress required to break the chemical bonds between two atoms of two parallel planes, creating a fracture surface or cohesive theoretical strength. The calculated values for different materials according to the model of Orowan are generally higher than those obtained by the model of Frenkel ${ }^{5}$. According to Meyers and Chawla ${ }^{6}$, the values for iron, calculated according to the models of Frenkel and Orowan are approximately 13 and $67 \mathrm{GPa}$, respectively.

Experimentally, the strength of pure iron presents two extremes separated by three orders of magnitude. The upper limit, around $13 \mathrm{GPa}$, has been measured in whiskers of about $1.6 \mu \mathrm{m}$ in diameter ${ }^{7}$. The lower limit, between 10 and $15 \mathrm{MPa}$, has been observed in annealed monocrystals of pure iron and tested at room temperature ${ }^{8}$. None of these two materials (whiskers or monocrystals) has any significance in terms of structural applications. On the other hand, commercial steels are available in different geometries, present a broad spectrum of strength and a large area of applications. Among the ultra-high-strength steels, historically piano wire (hypereutectoid steel) must be pointed out, with a tensile strength between 1600 to $3300 \mathrm{MPa}$, according to its diameter ${ }^{9}$. Recent research work ${ }^{10}$ reported tensile strength values of up to $7 \mathrm{GPa}$ obtained in such a wire. To attain such a high strength level, a $0.54 \mathrm{~mm}$ dia. steel wire containing $0.98 \%$ carbon, austenitized at $950{ }^{\circ} \mathrm{C}$ for 20 seconds, which following suffered a eutectoid transformation at $580{ }^{\circ} \mathrm{C}$ for 20 seconds, has been cooled to room temperature and finally wire drawn down to $20 \mu \mathrm{m}$, approximately ${ }^{10}$. Once more, similarly to the whiskers, the minute diameter limits the usage of these exciting materials. It is important also to mention that in the technical literature, there is no clear definition of what an ultra-high-strength material is.

Steels are generally classified ${ }^{11}$ in three strength levels: low, medium, and high. This classification is based using the $(\mathrm{E} / \mathrm{YS})$ ratio, where $\mathrm{E}$ is the elasticity modulus, and 
YS is the yield strength. Steels having E/YS greater than 300 are considered as being of low strength, between 300 and 150 of medium strength, and lower than 150 are regarded as high strength steels ${ }^{11}$. The more common maraging steels present (E/YS) lower than 150: maraging $200(\mathrm{E} / \mathrm{YS}=133)$; maraging $250(\mathrm{E} / \mathrm{YS}=108)$; maraging 300 (E/YS=92); maraging $350(\mathrm{E} / \mathrm{YS}=83)$ and maraging $400(\mathrm{E} / \mathrm{YS}=69)$. Some classes of the maraging 400 steels are frequently denominated as being ultra-high-strength. In the absence of a clear definition for the ultra-high-strength steels in the literature, in the present paper, all steels with (E/YS) lower than 75, which corresponds to a yield strength of about $2500 \mathrm{MPa}$, will be considered as being ultra-high-strength.

Among the ultra-high-strength materials, available in the market in the various geometries and produced by wellknown processes, maraging steels must be pointed out, that can present a YS over $3 \mathrm{GPa}^{12}$. In the Fe-Ni system, the base for the maraging steels, man has been using them before the discovery of the chemical element Ni (in 1751), and before the birth of the commercial Ni-alloyed steels, around $1888 / 1889^{13}$. There is plenty of archaeological evidence that meteorites, in general, Fe-Ni alloys, have been used by our ancestors in the pre-history to produce weapons, tools, and jewelry ${ }^{13}$. For instance, the Bendegó meteorite weighing $5360 \mathrm{~kg}$, found in the outback of Bahia (Brazil) which is part of the National Museum (Rio de Janeiro) since 1888, has the following chemical composition (wt.\%): $\mathrm{Fe}=95.1 \%$; $\mathrm{Ni}=3.9 \%$ and other elements $=1.0 \%{ }^{14}$.

Maraging steels have been initially proposed (a patent has been deposited on Sept. 11, 1959, and granted Jun. $11,1964)$ by Clarence George Bieber ${ }^{15,16}$ of The International Nickel Company Inc., having a Ni content of about 25\%. Following, in 1962, other researchers of the same company published a paper $^{17}$ on maraging steels with a Ni content of about $18 \%$, which was the elemental composition that predominated due to its superior toughness. Maraging steels are practically exempt from the carbon. They present (after air cooling starting from the austenitic field), a ductile and tough non-twinned martensite (see Figure 2) in the form of packets or lath martensite ${ }^{18,19}$. This, in turn, can be submitted, subsequently, even to large cold rolling thickness reductions ${ }^{19}$. The massive increase in strength is associated with precipitation hardening caused by nanometric sized intermetallic particles that precipitate during subsequent aging of the martensite ("maraging"), in the temperature range of 400 to $600{ }^{\circ} \mathrm{C}^{17}$.

Maraging steels present a very favorable start $\left(\mathrm{M}_{\mathrm{S}}\right)$ and finish $\left(\mathrm{M}_{\mathrm{f}}\right)$ martensitic transformation temperatures, i.e., well above room temperature ${ }^{20}$. Moreover, the usual aging temperatures are situated bellow the temperature for the transformation of martensite into austenite $\left(A_{S}\right.$ and $\left.A_{f}\right)$. Figure 3 shows the dilatometric curve presenting the main phase transformations that occur in a maraging $350 \mathrm{steel}^{20}$ (see typical composition in Table 1).

Starting from the 70 s maraging steels have been developed ${ }^{21}$ with increasing strength (and decreasing toughness), with the $\mathrm{Fe}-18 \% \mathrm{Ni}-\mathrm{Co}-\mathrm{Mo}^{21-23}$ base composition, as the maraging 200, 250,300, and 350 presented in Table 1. The numbers mentioned represent the maximum ultimate strength (ksi) obtained after aging. With the passing

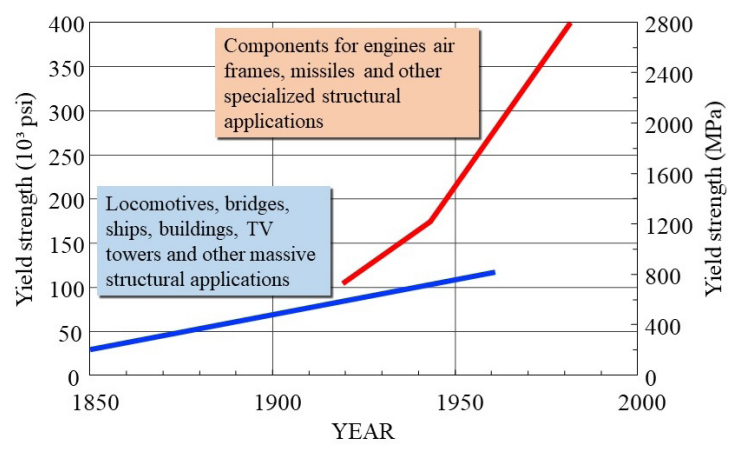

Figure 1. Yield strength increase in structural steels since $1850^{2}$.

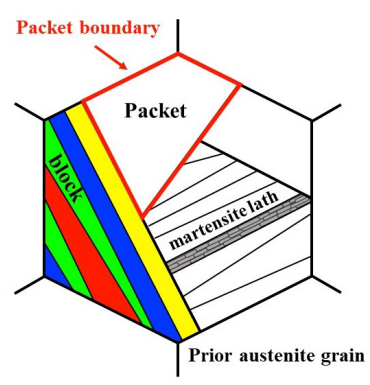

(a)

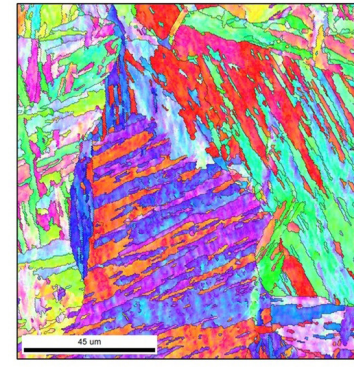

(b)
Figure 2. Schematic microstructure of lath martensite in maraging steels: (a) schematic presentation ${ }^{18}$; (b) EBSD map of the maraging 350 steel $^{19}$.

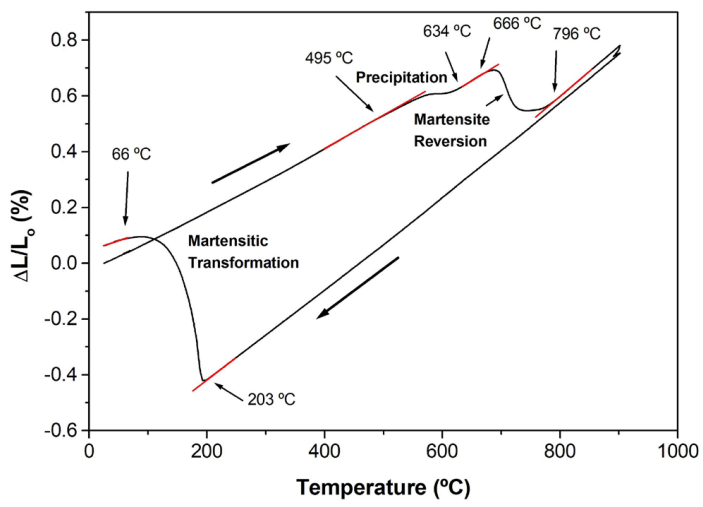

Figure 3. Dilatometric curve of heating and cooling for a maraging 350 steel, heating rate $=1{ }^{\circ} \mathrm{C} / \mathrm{s}^{20}$.

years, thoughts were to increase even more the strength of maraging steels. The base composition should be modified deriving ${ }^{12,24,25}$ maraging steels with a YS in the order of $3 \mathrm{GPa}$, using the $\mathrm{Fe}-13 \% \mathrm{Ni}-15 \% \mathrm{Co}-10 \% \mathrm{Mo}-\mathrm{Ti}$ base composition. This new class of steels, commercially available since the ' $80 \mathrm{~s}$, became known popularly as maraging 400 and 450 steels.

It is worth mentioning that the YS of $400 \mathrm{ksi}(2760 \mathrm{MPa})$ seems to represent an upper boundary for the maraging steels with $18 \% \mathrm{Ni}^{23}$ and that the lower limit for the $13 \% \mathrm{Ni}-15 \% \mathrm{Co}-\mathrm{Mo}-\mathrm{Ti}^{12,13,24}$ maraging steels. The characteristics and particularities of the precipitation hardening of these new ultra-high-strength maraging steels have been studied with the help of transmission electron microscopy ${ }^{12,24,26,27}$ and 
have shown that after aging the reiterated presence of three types of nanometric sized precipitates: $(\mathrm{Ni}, \mathrm{Fe})_{3}(\mathrm{Mo}, \mathrm{Ti})$; $\mu$ - $(\mathrm{Fe}, \mathrm{Co})_{7} \mathrm{Mo}_{6}$ and the Laves phase $(\mathrm{Fe}, \mathrm{Co})_{2}(\mathrm{Mo}, \mathrm{Ti})$. On the other hand, several characteristics of the phase transformations and the hardening mechanisms acting in this new class of maraging steels require complementary and more detailed studies. It should be pointed out also that the subject of the present paper is actual and continues raising the interest of several important research groups ${ }^{28}$.

Among the several applications of the maraging steels, it should be mentioned both for typical civil applications such as plastic injection dies ${ }^{29}$, as for applications in missiles. One of the more strategical uses of the maraging steels, happens in the form of sheet and thin-walled tubings, in the construction of ultracentrifuges for uranium isotopic enrichment ${ }^{25,30}$. Two characteristics worth mentioning that made a substantial contribution to the selection of maraging steels in several applications are: the martensite allows good workability and machinability, which facilitates attaining various geometries after quenching and that the geometries of the end products change very little (dimensional stability) during aging.

\section{Acting Strengthening Mechanisms in Maraging Steels}

The high strength levels in the maraging steels have been attained due to a synergistic combination of three procedures: optimization of the chemical composition, the right combination of precipitation heat treatment with the hot plastic working of the austenite (ausforming), and/or through the cold working of martensite (marforming) and by avoiding phenomena such as the reversion of martensite into austenite, the coarsening of the microstructure and the unwanted precipitation of some intermetallic phases. In the following, the three mentioned procedures will be discussed.

A careful observation of Table 1, wherein the chemical compositions of the maraging steels are presented, reveals the main ways followed by the researchers aiming at the strength increase in this class of steels. The most relevant hardening mechanism in the maraging steels is the hardening due to the precipitation of fine particles, of intermetallic compounds, coherent or semi-coherent with the martensitic matrix (BCC), such as $\mathrm{Ni}_{3} \mathrm{Mo}, \mathrm{Ni}_{3} \mathrm{Ti}$ and its variations $\mathrm{Ni}_{3}(\mathrm{Ti}, \mathrm{Mo})$ and $\mathrm{Ni}_{3}(\mathrm{Mo}, \mathrm{Ti})$, as well as the $\mathrm{Fe}_{2} \mathrm{Mo}$ Laves phase and its variants $(\mathrm{Fe})_{2}(\mathrm{Mo}, \mathrm{Ti})$ and $(\mathrm{Fe}, \mathrm{Co})_{2} \mathrm{Mo}^{23,31}$. The YS of maraging steel after aging is approximately threefold that after austenitizing and air cooling, i.e., immediately before aging. In terms of hardness, the increase due to precipitation is about 65 and $75 \%$ for the 250,300 , and 350 steels, and even more substantial for the 400 and 450 steels. Hence, it is not surprising that the primary strategy employed to increase the strength in the maraging steels has been to increase the volume fraction of precipitates that cause hardening, i.e., through the increase of the molybdenum and titanium contents of the steel. Moreover, the addition of cobalt leverages the hardening effect of the molybdenum, frequently called the synergistic molybdenum-cobalt effect ${ }^{32}$. Figure 4 clearly shows the effect of cobalt on the precipitation kinetics and the hardening level of a Fe-18Ni-5Mo alloy ${ }^{33,34}$. The presence of cobalt accelerates both the decrease in resistivity to lower values (Figure 4a) as the hardness increase to higher values (Figure $4 b$ ). Such behavior can be explained by the higher

Table 1. Typical nominal chemical compositions of maraging steels (wt.\%) ${ }^{21-23}$

\begin{tabular}{cccccr}
\hline Element/type & 200 & 250 & 300 & 350 & 18 \\
\hline $\mathbf{N i}$ & 18 & 18 & 18 & 12.5 & 13 \\
\hline $\mathbf{C o}$ & 8.5 & 8.5 & 9.0 & 4.2 & 15.0 \\
\hline $\mathbf{M o}$ & 3.3 & 5.0 & 5.0 & 1.6 & $<0.0$ \\
\hline $\mathbf{T i}$ & 0.2 & 0.4 & 0.7 & 0.1 & 0.2 \\
\hline $\mathbf{A l}$ & 0.1 & 0.1 & 0.1 & $<0.03$ & 0.02 \\
\hline $\mathbf{C}$ & $<0.03$ & $<0.03$ & $<0.03$ & $<0.20$ & $<0.20$ \\
\hline $\mathbf{S i}+\mathbf{M n}$ & $<0.20$ & $<0.20$ & $<0.20$ & & \\
\hline
\end{tabular}

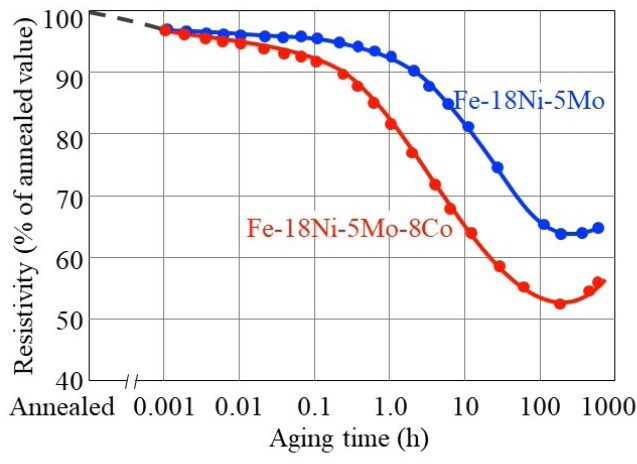

(a)

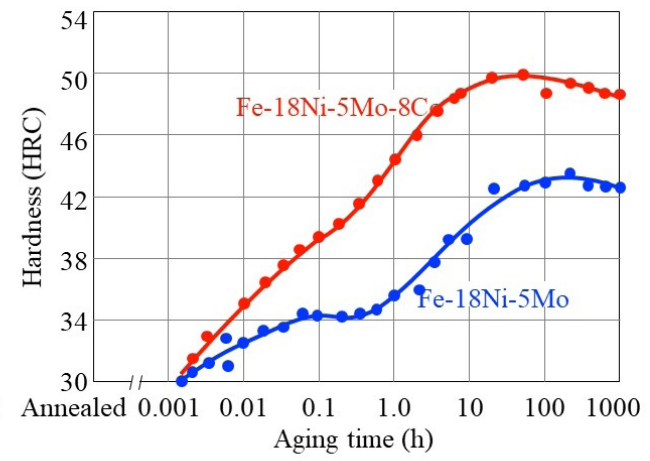

(b)

Figure 4. Effect of the addition of $8 \%$ Cobalt on the variation of the electrical resistivity(a) and the Rockwell C hardness (b) in a Fe$18 \%$ Ni- $5 \%$ Mo alloy ${ }^{33,34}$. 
volume fraction of precipitates with the rise of the cobalt content in the alloy.

On the other side, for $\mathrm{Fe}-17 / 19 \% \mathrm{Ni}$ alloys, the upper limit for additions of molybdenum is about $5 \mathrm{wt} \%$. To increase the molybdenum content even further and keep the martensitic phase it is necessary to reduce the nickel content $^{35}$, according to Figure 5, which led to the development of the Fe-13Ni-15Co-10Mo maraging steels (see Table 1).

Regarding Figure 5, it is relevant to mention that increasing the addition of molybdenum requires higher homogenizing temperatures after casting and higher solution annealing after

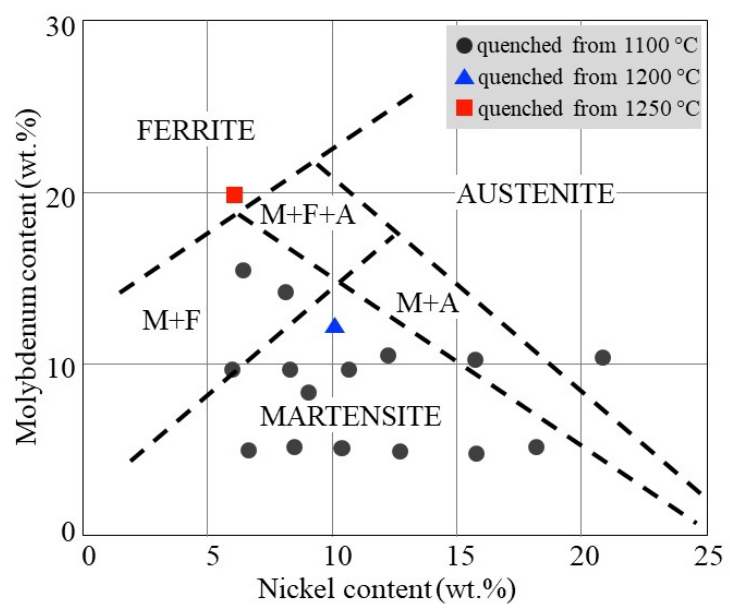

Figure 5. Fe-Ni-Mo diagram bound by the different phases $^{35}$. mechanical working. These temperatures are much higher, in the range of 1000 and $1250{ }^{\circ} \mathrm{C}$, if compared to the usual austenitizing temperatures $\left(840 / 850^{\circ} \mathrm{C}\right)$ employed for the traditional $\mathrm{Fe}-18 \% \mathrm{Ni}$ maraging steels.

Another critical effect of cobalt on the maraging steels is its plausible effect on decreasing the stacking fault energy (SFE) of the austenite ${ }^{36}$. The decrease of the SFE hinders the dislocation cross-slip, decreasing its mobility, making difficult the formation of dislocation cells, and increasing strength by work hardening. The increase resulting from the average dislocation density fosters, even more, the sites for the heterogeneous nucleation of precipitates. The effect of cobalt has direct consequences on the hot working of the austenite (ausforming) and indirect on the cold working of the martensite (marforming) and the precipitation hardening (maraging). In Figure 6, Hornbogen and Rittner ${ }^{12}$, presented schematically the different possibilities of thermal, thermomechanical, and mechanical-thermal treatments for the Fe-13Ni-15Co-10Mo family of maraging steels. According to the authors ${ }^{12}$, a YS over 3 GPa can be attained through high reductions during hot rolling (ausforming) combined with cold rolling (marforming) applied before aging (maraging).

During the processing of the ultra-high-strength maraging steels, it occurs or may occur some undesired microstructural modifications, which should be avoided. The main ones such as abnormal grain growth during the thermal treatments of homogenizing and solution annealing, particle coarsening during aging, generally associated with the partial reversion of martensite into austenite, and the unwanted precipitation of
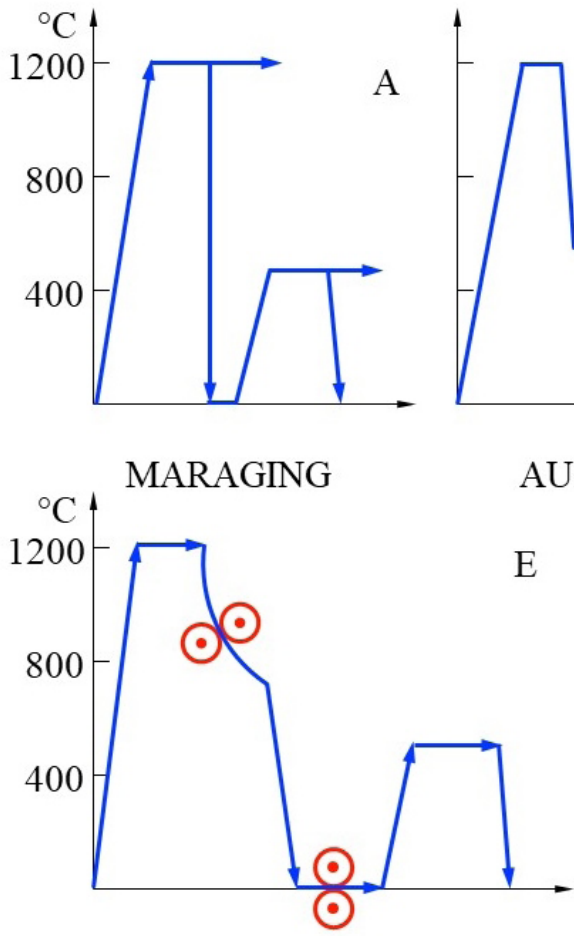

COMBINATION A-D
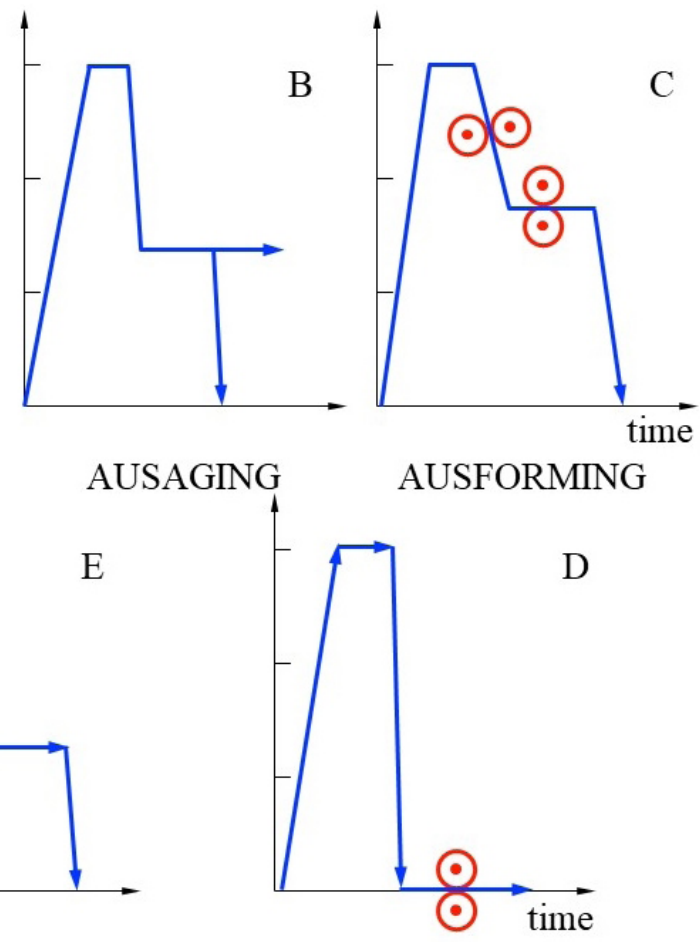

MARFORMING

Figure 6. Time-temperature diagrams illustrating different treatments and their combinations. Horizontal lines with arrows indicate the variable austenitizing $\left(1200^{\circ} \mathrm{C}\right)$ periods for intercritical annealing $\left(700^{\circ} \mathrm{C}\right)$ and aging $\left(450-600{ }^{\circ} \mathrm{C}\right)^{12}$. 
intermetallic phases, such as sigma $(\sigma)$, will be discussed in the following, focused on the Fe-13Ni-15Co-10Mo type steels.

According to the work of Hagiwara and Kawabe ${ }^{37}$, during the processing of the Fe-13Ni-15Co-10Mo maraging steels, after melting and casting under vacuum, ingots $\left(17.5 \mathrm{~kg}\right.$ ) have been homogenized at $1250^{\circ} \mathrm{C}$ for 24 hours, hot forged in the form of plates and air-cooled. Following they have been solution annealed at $1250{ }^{\circ} \mathrm{C}$ for one hour and air-cooled. The resulting average grain size was $850 \mu \mathrm{m}$. If by one side the processing cycle utilized, enabled that practically all solute was in solid solution homogeneously distributed, on the other side, the resulting grain size was a problem to be solved. One of the alternatives for the grain refinement is the repetitive thermal cycling martensite/ austenite. According to Nakazawa et al..$^{38}$, by adequately selecting the maximum austenitization temperature, five thermal cycles reduced the average grain size to lower than $50 \mu \mathrm{m}$. A second alternative is by hot rolling in the austenitic region $^{37,39}$. For instance, starting from a $40 \mathrm{~mm}$ thickness plate and applying four hot rolling passes (between 1200 and $900{ }^{\circ} \mathrm{C}$ ), down to a final thickness of $9 \mathrm{~mm}$, the average grain size obtained was $20 \mu \mathrm{m}$. If for any reason the processed material should be submitted to an additional austenitizing heat treatment, it should be remembered that the limit condition is $1000{ }^{\circ} \mathrm{C}-1 \mathrm{~h}$, because the higher temperatures and/or longer times induce unwanted grain growth $^{12}$. In principle, the minimum austenitizing temperature is defined by the $\mathrm{A}_{\mathrm{f}}$ (austenite finishing) temperature, i.e., by the temperature at which the austenite is completely formed during the heating of the martensite. In the case of DIN X2 NiCoMo 131510 steel, the $\mathrm{A}_{\mathrm{f}}$ temperature is around $830{ }^{\circ} \mathrm{C}^{12}$. Therefore, it is reasonable to assume that the austenitizing temperature of the steels should be selected within the 850 to $1000^{\circ} \mathrm{C}$ temperature range.

Figure 7 presents the aging curves for Fe-13Ni-15Co10.1Mo-0.2Ti maraging steel, clearly showing the superiority of the thermal treatment performed at $480{ }^{\circ} \mathrm{C}$ for $4 \mathrm{~h}$, attaining a Vickers hardness over $800 \mathrm{HV}$, corresponding to 65 in the Rockwell C (HRC) scale ${ }^{40}$.

Fukamachi et al. ${ }^{41}$ carried out a detailed identification work using transmission electron microscopy and electron diffraction of the precipitates that occur during the aging of Fe-13.01Ni-15.30Co-9.83Mo-0.24Ti maraging steel in three temperatures: $450 ; 500$ and $550{ }^{\circ} \mathrm{C}$. The aging curves are shown in Figure 8. Only two types of precipitates have been identified in the martensitic matrix: $\mathrm{Ni}_{3} \mathrm{Mo}$ and $\mathrm{Fe}_{2} \mathrm{Mo}$ (see Table 2). Initially occurs the precipitation of $\mathrm{Ni}_{3} \mathrm{Mo}$, however at peak hardness, for the three temperatures analyzed, $\mathrm{Ni}_{3} \mathrm{Mo}$ and $\mathrm{Fe}_{2} \mathrm{Mo}$, were present. In a general manner, one can affirm that the $\mathrm{Fe}_{2} \mathrm{Mo}$ Laves phase precipitated at higher temperatures and/or longer times than the $\mathrm{Ni}_{3} \mathrm{Mo}$ compound ${ }^{23,41}$. At peak hardness, the average precipitate size was about $5 \mathrm{~nm}^{41}$.

Menzel and $\mathrm{Klaar}^{23}$ presented quantitative results of the volume fraction of reverted austenite using X-ray diffraction as a function of temperature. After two hours of exposure at $500{ }^{\circ} \mathrm{C}$, no martensite to austenite reversion could be detected using X-ray diffraction, however at $550{ }^{\circ} \mathrm{C}$ already some evidence of the reversion has been observed, and at $600{ }^{\circ} \mathrm{C}$ about $15 \%$ austenite has been detected. On the one hand, the formation of reverted austenite is associated with a decrease in strength and an increase in fracture toughness. On the other hand, the formation of coarse particles of the intermetallic particles $\sigma-\mathrm{Fe}$ Mo and $\mu-\mathrm{Fe}_{7} \mathrm{Mo}_{6}$ (see Table 2), detected by Drapier et al. ${ }^{40}$, apart from depleting molybdenum from the martensite ${ }^{42}$, may incur in toughness loss.

Despite some noteworthy research works, using several complementary techniques to characterize the microstructure that has been done more recently ${ }^{43,44}$, the precipitation in maraging steels of the Fe-13Ni-15Co-10Mo-Ti type, is still not completely clarified.

It must be pointed out that the maraging steels also present a great potential for improvement and the possibility of attaining strength levels well over the YS of $2500 \mathrm{MPa}$.

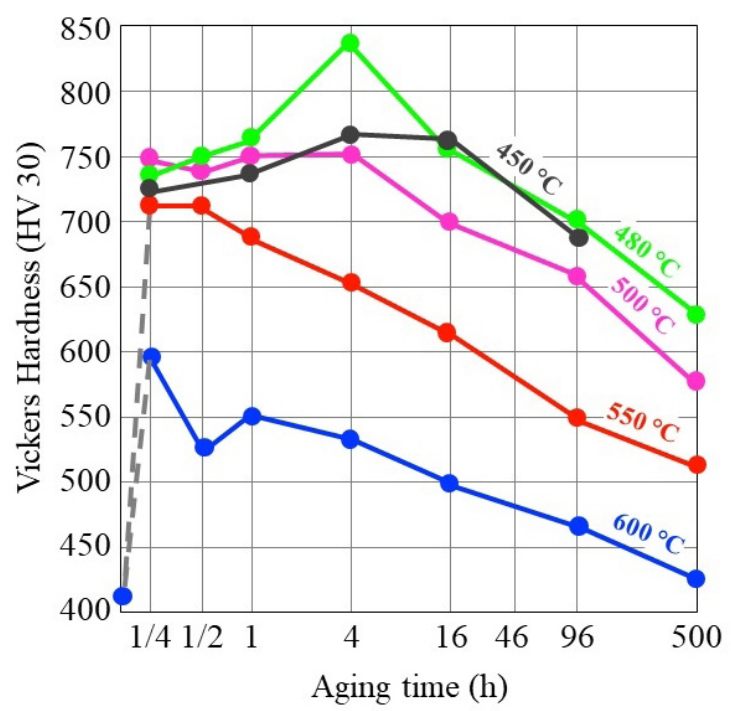

Figure 7. Vickers hardness variation as a function of aging time (in $\mathrm{h}$.) for several temperatures for the Fe-13Ni-15Co-10.1 Mo-0.2Ti steel ${ }^{40}$.

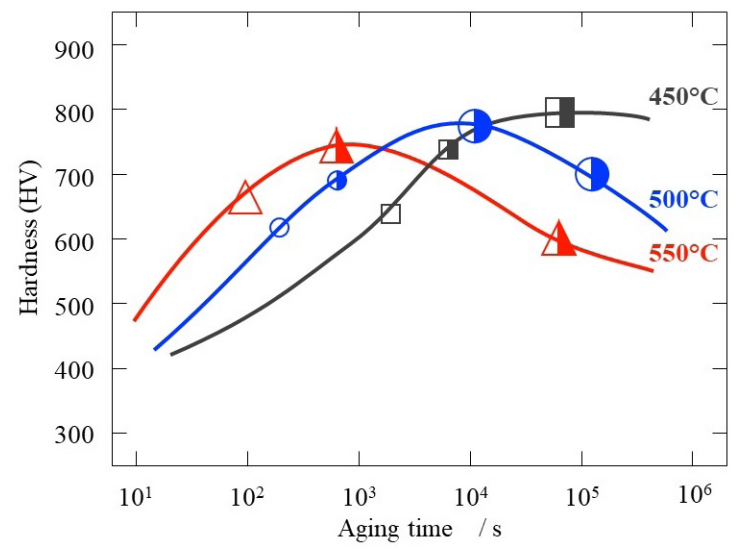

Figure 8. Vickers hardness as a function of aging time (in seconds) for the Fe-13.01 Ni-15.30Co-9.83Mo-0.24Ti steel for three temperatures: $450{ }^{\circ} \mathrm{C}$ (squares); $500^{\circ} \mathrm{C}$ (circles) and $550{ }^{\circ} \mathrm{C}$ (triangles). Open symbols indicate the presence of $\mathrm{Ni}_{3} \mathrm{Mo}$ only, semi-closed indicate the simultaneous presence of $\mathrm{Ni}_{3} \mathrm{Mo}$ and $\mathrm{Fe}_{2} \mathrm{Mo}$. The size of the symbols indicates the size of the precipitates: small and large mean smaller and larger than $4 \mathrm{~nm}$, respectively ${ }^{41}$. 
Table 2. Main intermetallic compounds that may occur in the Fe-13Ni-15Co-10Mo steel ${ }^{23,40-42}$

\begin{tabular}{|c|c|c|c|c|}
\hline Phase & Approx. composition & Crystal structure & Spacial group & Lattice parameter (nm) \\
\hline $\mathrm{Ni}_{3} \mathrm{Mo}$ & $(\mathrm{Ni}, \mathrm{Fe})_{3}(\mathrm{Mo})$ & Orthorhombic & Pmmm & $\begin{array}{l}\mathrm{a}=0.506 \\
\mathrm{~b}=0.422 \\
\mathrm{c}=0.445\end{array}$ \\
\hline $\mathrm{Fe}_{2} \mathrm{Mo}(\lambda)$ & $(\mathrm{Fe}, \mathrm{Co})_{2}(\mathrm{Mo})$ & Hexagonal & $\mathrm{P}_{3} / \mathrm{mmc}$ & $\begin{array}{l}a=0.473 \\
c=0.772\end{array}$ \\
\hline $\operatorname{Sigma}(\sigma)$ & Fe-Mo & Tetragonal & $\mathrm{P} 42 / \mathrm{mnm}$ & $\begin{array}{l}\mathrm{a}=0.92 \\
\mathrm{c}=0.48\end{array}$ \\
\hline Mu $(\mu)$ & $(\mathrm{Fe}, \mathrm{Co})_{7} \mathrm{Mo}_{6}$ & Rhombohedral & $\mathrm{R}-3 \mathrm{~m}$ & $\begin{array}{l}\mathrm{a}=0.475^{*} \\
\mathrm{c}=2.566^{*}\end{array}$ \\
\hline
\end{tabular}

* In hexagonal indexation notation

Table 3. Chemical composition (wt.\%) of five experimental alloys and the Vickers hardness (HV 0.3) after solution annealing $\left(850^{\circ} \mathrm{C}-1 \mathrm{~h} /\right.$ air) and aging $\left(480{ }^{\circ} \mathrm{C}-5 \mathrm{~h} / \mathrm{H}_{2} \mathrm{O}\right)$.

\begin{tabular}{|c|c|c|c|c|c|}
\hline Alloy & $\mathrm{A}$ & $\mathrm{B}$ & $\mathrm{C}$ & $\mathrm{D}$ & $\mathrm{E}$ \\
\hline $\mathrm{Ni}$ & 12.61 & 14.11 & 13.08 & 13.40 & 14.06 \\
\hline $\mathrm{Co}$ & 14.49 & 14.27 & 15.35 & 14.96 & 15.21 \\
\hline Mo & 11.12 & 11.40 & 11.30 & 7.51 & 15.02 \\
\hline $\mathrm{Ti}$ & 0.060 & 0.400 & 0.88 & 0.250 & 0.240 \\
\hline $\mathrm{Al}$ & $<0.01$ & 0.01 & 0.05 & 0.06 & 0.04 \\
\hline $\mathrm{C}$ & 0.021 & 0.014 & 0.024 & 0.023 & 0.021 \\
\hline $\mathrm{Si}$ & 0.190 & 0.060 & 0.080 & 0.150 & 0.060 \\
\hline $\mathrm{Mn}$ & 0.220 & 0.030 & 0.050 & 0.160 & 0.040 \\
\hline HV (Solution annealed) & $391 \pm 5$ & $396 \pm 9$ & $407 \pm 4$ & $335 \pm 2$ & $437 \pm 3$ \\
\hline HV (Aged) & $805 \pm 4$ & $769 \pm 16$ & $806 \pm 3$ & $689 \pm 6$ & $727 \pm 10$ \\
\hline
\end{tabular}

Table 3 shows five experimental chemical compositions, along with the hardness values in the solution annealed and aged condition.

Alloys A, B, C, and D presented a fully martensitic microstructure after solution annealing at $850{ }^{\circ} \mathrm{C}$ and air cooling, while the alloy E presented a significant amount of austenite. Upon Aging at $480^{\circ} \mathrm{C}$ for $5 \mathrm{~h}$, alloys A, B, and $\mathrm{C}$ presented higher hardness value following values that have been forecast in Figures 7 and 8. The lower value of alloy $\mathrm{E}$, as compared to the alloys $\mathrm{A}, \mathrm{B}$, and $\mathrm{C}$, is due to the presence of austenite in alloy $\mathrm{E}$ and also to several larger particles, molybdenum rich, not being completely dissolved during solution annealing, reducing the precipitate volume fraction in the form of fine particles during subsequent aging. The coarse undissolved particles during solution annealing may also explain the higher hardness of the alloy $\mathrm{E}$ in the solution annealed condition.

It was essential to mention that already in 1963; it has been possible to evaluate with reasonable precision the YS of the $13 \mathrm{Ni}-15 \mathrm{Co}-10 \mathrm{Mo}-0.2 \mathrm{Ti}$ steel with the help of Equation 1, given below ${ }^{45}$. Finding the YS of approximately $3110 \mathrm{MPa}$.

$Y S(\mathrm{MPa})=104+63(\% \mathrm{Co})+195(\% \mathrm{Mo})+552(\% \mathrm{Ti})$

Another aspect of being mentioned is that Equation 1 does not contemplate the $\mathrm{Ni}$ content (at that time all commercial maraging steels had about $18 \% \mathrm{Ni}$ ) and considers the elements cobalt, molybdenum, and titanium, main contributors to the strength increase.

\section{The Challenge of the Toughness Loss with the Strength Increase}

Toughness (and ductility) decrease of steels with the increase of hardness (and of tensile strength) is a sort of "practical rule" well known by metallurgists for millennia. Figure 9 portrays this behavior for several maraging steel types. One alternative possibility is to sacrifice part of its strength in favor of toughness increase, through microstructural modifications. In the case of carbon steels, this is typically obtained through tempering applied after quenching heat treatments. In the case of maraging steels, a similar procedure may be adopted. Selecting the aging time and/or temperature that cause some precipitate coarsening, by overaging, with the consequent strength decrease and toughness increase, a fair compromise between these two properties may be attained. In the case of the ultra-high-strength X2 NiCoMo 131510 steel, success chances are increased. An alternative and the complementary path is to optimize de molybdenum content in the Fe-13Ni-15Co matrix, in the range of 7.5 to $15 \%$ Mo.

At this point, it is crucial to raise the following question: is there a minimum level of acceptable toughness for a structural material? The plane strain fracture toughness $\left(\mathrm{K}_{\mathrm{Ic}}\right)$ measures the resistance to crack and fracture propagation. Equation 2, given below ${ }^{11}$, relates the $\mathrm{K}_{\mathrm{Ic}}$ value of a material with the critical stress $\left(\sigma_{\text {crit }}\right)$ for the crack propagation and its maximum length $\left(\mathrm{a}_{\max }\right)$. 


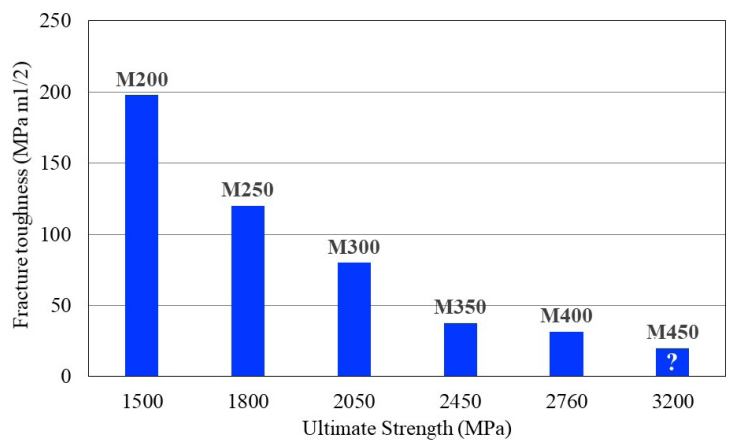

Figure 9. Variation of fracture toughness $\left(\mathrm{K}_{\mathrm{IC}}\right)$ with the UTS of maraging steels in the condition of maximum (peak) hardness on $\operatorname{aging}^{22,23,34}$.

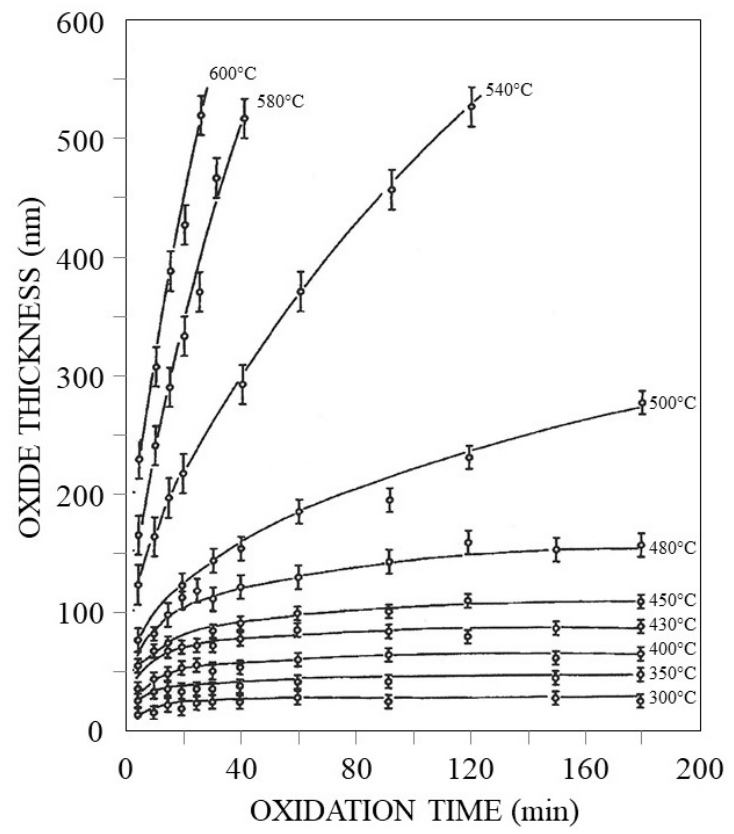

Figure 10. Oxidation kinetics (variation of the oxide film thickness with exposure time) in the air of a maraging 300 steel at various temperatures ${ }^{48}$.

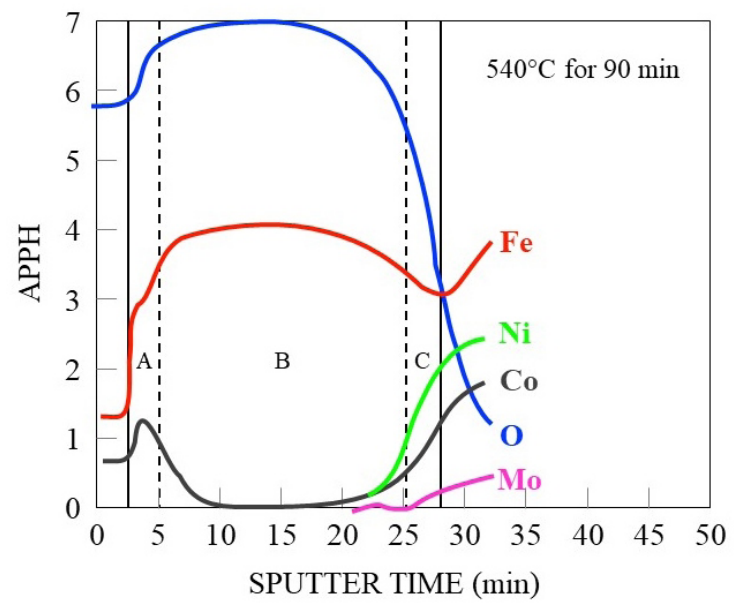

Figure 11. Concentration profile of several elements $(\mathrm{O}, \mathrm{Fe}, \mathrm{Ni}, \mathrm{Co}, \mathrm{Mo})$ obtained by AES-AIS in the maraging 300 steel after exposure at $540{ }^{\circ} \mathrm{C}$ for 90 minutes. The sputtering rate used was $19 \mathrm{~nm} / \mathrm{min}^{49}$. $a_{\max }=\frac{K_{I c}{ }^{2}}{\pi \sigma_{c r i t}^{2}}$

With the help of Equation 2, it is possible to evaluate $\mathrm{K}_{\mathrm{Ic}}$ for given critical stress $\left(\sigma_{\text {crit }}\right)$ and a maximum acceptable crack length $\left(\mathrm{a}_{\max }\right)$. Criteria to establish the value for the full proper crack length may be the minimum size detectable by non-destructive tests, such as radiography and ultrasonography. Using such criteria, for a crack length of just $0.1 \mathrm{~mm}$ at a stress of $3000 \mathrm{MPa}$, the calculated value of KIc is $53 \mathrm{MPa}$. $\mathrm{m}^{1 / 2}$. We may conclude that to obtain maraging steels with an ultra-high-strength and acceptable toughness is not a trivial task.

\section{Resistance to Oxidation and Corrosion}

In several applications, metallic materials are subject to some type of ambient degradation being external or superficial, i.e., that starts at the surface, such as oxidation, cavitation, or abrasive wear. In a broad sense, in the oxidative processes, the metallic atoms give up some electrons, as it occurs in the oxidation and several types of corrosion. The emphasis of this item will be oxidation at high temperatures when the metallic materials react with oxygen, air, or water in the gaseous phase.

One may affirm that pure iron and low alloy steels, which in general present a maximum of $2 \mathrm{wt} . \%$ solute, in comparison with most metals and alloys, have good oxidation and corrosion resistance. For instance, low alloy steel has good oxidation resistance in the air $\left(10 \mathrm{mg} / \mathrm{cm}^{2}\right.$ after $1000 \mathrm{~h}$ exposition) up to about $550{ }^{\circ} \mathrm{C}$, while austenitic stainless steels of the $18 \% \mathrm{Cr}-8 \% \mathrm{Ni}$ type present the same oxidation rate up to $850{ }^{\circ} \mathrm{C}^{46,47}$.

Maraging steels are exposed to high temperatures during the several stages of its processing, such as during the homogenizing heat treatment after casting $\left(1200-1250^{\circ} \mathrm{C}\right)$, during solution annealing and austenitization $\left(850-1100^{\circ} \mathrm{C}\right)$ before quenching, and subsequent aging $\left(400-500{ }^{\circ} \mathrm{C}\right)$. Figure 10 illustrates the oxide thickness variation with the exposure time in the air for the 300 to $600{ }^{\circ} \mathrm{C}$ temperature range ${ }^{48}$. Two types of behavior, both protective, are shown: between 300 and $480{ }^{\circ} \mathrm{C}$ the oxide layer growth is logarithmic, and between 500 and $600{ }^{\circ} \mathrm{C}$ is parabolic. The logarithmic behavior is typical of very protective oxides with a thickness smaller than 100 to $200 \mathrm{~nm}$ and a relatively small electric conductivity, i.e., with low charge mobility. Oxide films in iron, nickel, and aluminum pure metals follow the logarithmic growth at low temperatures ${ }^{49}$. The parabolic behavior is common to most metals and occurs in a temperature range in which the integrity of the film oxide is preserved, presenting adherence and is devoid of cracks.

The work of Greyling et al. ${ }^{48}$, carried out with Auger Electron Spectroscopy (AES), in conjunction with sputtering using argon ions (Argon Ion Sputtering; AIS), has performed a systematic study of the chemical composition of the oxide film, as shown in Figure $11^{48}$. Such a combination of techniques (AES/AIS) allows obtaining the variation of the chemical composition of the oxide film as a function of the distance. In Figure 11, three regions (A, B, and C), can be observed. In the most outer region $(\mathrm{A})$, the concentration profile indicates the existence of a mixture of oxides 
$\mathrm{CoO} / \alpha-\mathrm{Fe}_{2} \mathrm{O}_{3}$, while in the intermediate region (B) occurs the predominance of the $\alpha-\mathrm{Fe}_{2} \mathrm{O}_{3}$. Near to the oxide/metal interface $(\mathrm{C})$ occurs a mixture of spinels, i.e., a mix of oxides with the general formula $(\mathrm{X})(\mathrm{Y})_{2} \mathrm{O}_{4}$, where $\mathrm{X}$ represents the cations that occupy the tetrahedral positions and $\mathrm{Y}$ the cations that occupy the octahedral positions of the cubic structure (or tetragonal), formed by the oxygen anions. $\mathrm{X}$ and $\mathrm{Y}$ may be ions of the same atom as is the case of magnetite $\mathrm{Fe}_{3} \mathrm{O}_{4}$, however, presenting diverse valences ${ }^{50}$.

Albuquerque Vicente et al. ${ }^{25}$ investigated the oxidation of maraging steels shown in Table 3 after exposure for $5 \mathrm{~h}$ at a typical homogenizing temperature $\left(1250^{\circ} \mathrm{C}\right)$ for these steels with a high molybdenum content. Results show a good correlation between the increase in the molybdenum content with the oxidation resistance. X-ray diffraction analysis revealed that the principal oxide was $\mathrm{Fe}_{2} \mathrm{O}_{3}$; however, more detailed studies related to the modification of the film oxide along the thickness have not been made. Figure 12 shows a micrography of alloy A of Table 3, after exposing it in air.

In the micrography of Figure 12, several different regions may be observed. Initially, with EDS analysis of the non-oxidized internal region, only five elements have been detected with the composition (wt.\%): $\mathrm{Fe}=62.8 \%$; $\mathrm{Co}=15.7 \% ; \mathrm{Ni}=12.4 \% ; \mathrm{Mo}=8.9 \% ; \mathrm{Si}=0.2 \%$. Comparing these values with those presented in Table 3 , we may conclude that the agreement is reasonable.

Following, still with the EDS, the film or the most external layer with a homogeneous grey color, the composition obtained was (wt. $\%$ ): $\mathrm{Fe}=63 \% ; \mathrm{O}=28.2 \%$; $\mathrm{Co}=2.9 \% ; \mathrm{C}=3.1 \%$; $\mathrm{Na}=1.7 \% ; \mathrm{Mo}=0.4 \% ; \mathrm{Si}=0.3 \% ; \mathrm{Ca}=0.3 \%$. Carbon, sodium, and calcium concentrations may be considered as impurities. The conclusion is that the external film, with a grey color, is a practically pure iron oxide with a stoichiometry between $\mathrm{Fe}_{2} \mathrm{O}_{3}$ or $\mathrm{Fe}_{3} \mathrm{O}_{4}$, given that the EDS technique does not have enough accuracy to allow the differentiation between these two oxides. Right under the grey-colored film of oxide a region with a thickness of little over $10 \mu \mathrm{m}$ both $\mathrm{Fe}_{2} \mathrm{O}_{3}$ or $\mathrm{Fe}_{3} \mathrm{O}_{4}$ may be observed, containing two phases: a light grey and another white and continuous. The white layer had the composition (wt. $\%$ ): $\mathrm{Fe}=40.4 \%$; $\mathrm{Co}=28.2 \%$; $\mathrm{Ni}=26.4 \% ; \mathrm{Mo}=5.1 \%$. The light gray composition was (wt. $\%$ ): $\mathrm{Fe}=31 \%$; $\mathrm{Mo}=29.8 \% ; \mathrm{O}=17.2 \%$; $\mathrm{Co}=11.4 \%$; $\mathrm{Ni}=9.6 \% ; \mathrm{Si}=0.3 \% ; \mathrm{Mn}=0.6 \%$. This analysis strongly suggests that the layer is composed of a (light grey) oxide dispersed in a (white) metallic matrix. The chemical composition of the white continuous layer suggests that it had FCC structure (austenite), that is, oxidation of maraging steels induces the formation of austenite.

Even though maraging steels present a moderate oxidation resistance, for some applications in aggressive environments, such as uranium hexafluoride, the formation of a protective film can avoid the corrosive attack on maraging steels, Pfistermeister et al. ${ }^{51}$ suggested a process in which the steel surface is exposed to overheated water vapor, between $450 \mathrm{e}$ $520^{\circ} \mathrm{C}$ for 1 to $3 \mathrm{~h}$ duration, when the protective $\mathrm{Fe}_{3} \mathrm{O}_{4}$ film is formed.

The patent ${ }^{51}$ mentions that the process can be used for other steels, but has been developed aiming at the maraging steels with a chemical composition range of (wt.\%): $\mathrm{Ni}=10-26$; $\mathrm{Co}=6-18 ; \mathrm{Mo}=2-12 \mathrm{e} \mathrm{Ti}=0.5-2.0$. Rezek et al ${ }^{52}$ characterized

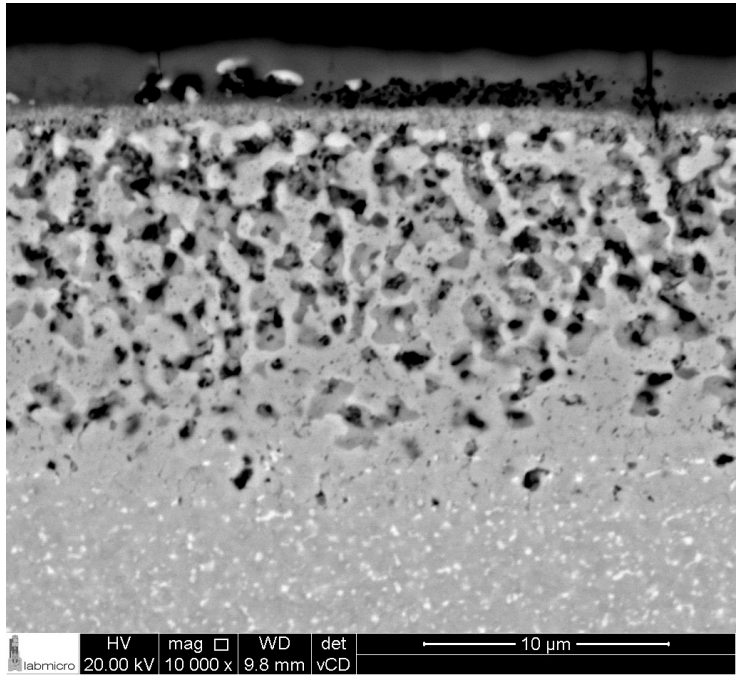

Figure 12. Transverse section of the oxidized plate during the thermal treatments of solution annealing and aging in the air of alloy A, observed in the SEM.

the crystalline structure (using X-ray diffraction) and the chemical composition of the oxide film (using AES/AIS and ESCA) that forms on the surface of maraging 250 steel exposed to superheated water vapor at $485^{\circ} \mathrm{C}$ for 3 hours. The X-ray diffractions showed the presence of an internal layer of austenite, followed by a magnetite $\left(\mathrm{Fe}_{3} \mathrm{O}_{4}\right)$ layer and a larger amount of hematite $\left(\mathrm{Fe}_{2} \mathrm{O}_{3}\right)$.

In general, maraging steels present a significantly higher corrosion resistance than low alloy steels ${ }^{53}$. For some applications, the corrosion resistance is an essential parameter in the material selection. In general, maraging steels present a corrosion resistance slightly superior to the HSLA (High Strength Low Alloy steels), however in salty solutions and acids maraging steels are well superior ${ }^{53}$. In general, maraging steels in maritime and industrial atmospheres present a corrosion rate of half of those offered by low alloy steels. Generally, corrosion resistance of non-aged maraging steels is superior if compared to the aged condition ${ }^{54,55}$.

For some applications, abrasive wear resistance offered by maraging steels is insufficient, and in these cases, ionic nitriding surface hardening is an interesting alternative $\mathrm{e}^{56-58}$. One of the advantages of ionic nitriding is that it can be performed simultaneously with aging at temperatures under $500{ }^{\circ} \mathrm{C}$, avoiding the temperature range where overaging of this steel occurs. Several studies have shown that the surface hardening coming from that thermochemical treatment is due to the formation of phases such as $\mathrm{Fe}_{4} \mathrm{~N}, \mathrm{Fe}_{3} \mathrm{~N}$ e $\mathrm{Fe}_{2} \mathrm{~N}$, which induce an increase in the wear resistance and surface corrosion resistance ${ }^{56,57}$. The usage of ionic nitriding for maraging steels has been promising in aerospace applications ${ }^{58}$.

\section{Future Perspectives}

It is reasonable to affirm that maraging steels, within the steel universe, are expensive and rare materials. Maraging steel production can be measured as being on the scale of thousandths of world steel production. Its price is higher than that of other high alloyed steels containing more than 
20 wt. \% alloying elements, such as austenitic stainless ${ }^{59}$ and duplex steels ${ }^{60}$.

Fabrication of maraging steels requires raw materials and processes that are special. With regards to the raw materials, the most restrictive requirement is its low carbon content, associated with the low phosphor and sulfur specified for the end product. Although they have available raw materials in the market, their cost is higher than those used in the production of standard steels. Concerning their fabrication processes, the first casting of maraging steels is generally carried out by Vacuum Induction Melting (VIM), followed by Vacuum Arc Remelting (VAR) and eventually followed by Electro-Slag Remelting (ESR). These are unique foundry and casting processes, i.e., different from those used in the fabrication processes for standard steels ${ }^{61}$. Summarizing, maraging charges are associated with smaller quantities, using more expensive technologies, nevertheless available, but still demanding technological improvements.

Among the most recent processing routes, additive manufacturing technology ${ }^{62}$ allows the fast production of complex geometry products, in small quantities at a smaller unit price. Apart from reducing costs, associated with post-production, it has to be considered that the end product is of the "near-net-shape" type, starting from a virtual model ${ }^{63}$. Additive manufacturing has been applied to maraging steels with exciting and promising results ${ }^{64-66}$. Figure 13 shows a typical microstructure of a maraging 300 steel processed by additive manufacturing using selective laser melting (SLM), wherein the fine microstructure can be observed, apart from the low level of defects, such as few pores ${ }^{67}$.

Figure 13a presents the top view of a manufactured structure where it is possible to observe the different directions in the cast material. Figure $13 \mathrm{~b}$ shows the side view of the structure, wherein the boundaries of the produced seams (apart from the martensitic structure), revealed by etching of the internal part of the seams.

Still regarding the price, maraging steels present in their a chemical composition between 30 and 40\% (wt.\%) (see Table 1) alloying elements relatively expensive, mainly nickel, cobalt, and molybdenum. Furthermore, the levels of carbon (less than 0.03 wt.\%), sulfur, and phosphor (less than $0.01 \mathrm{wt} . \%$ ) must be kept at a residual level, as low as possible. The unusual melting and remelting processes employed in the processing of maraging steels mentioned previously, apart from being expensive, are not used on the large-scale production, such as continuous casting used in other classes of steels. The large quantity of alloying elements in the maraging steels also requires high temperatures and long homogenizing times, followed by mechanical working procedures.

Despite the high cost, maraging steels are practically indispensable in various special applications including the strategical aeronautical, aerospace, nuclear, and military industries. For instance, in the uranium isotopic enrichment by centrifuges, the strength increase of the maraging steels allows increasing the maximum peripheral speed of the revolving components, which in turn, increase the isotopic separation performance; a 10\% increase in peripheral speed results in $46 \%$ increase in separation performance ${ }^{30}$. Another possible and promising application is the use in flywheels

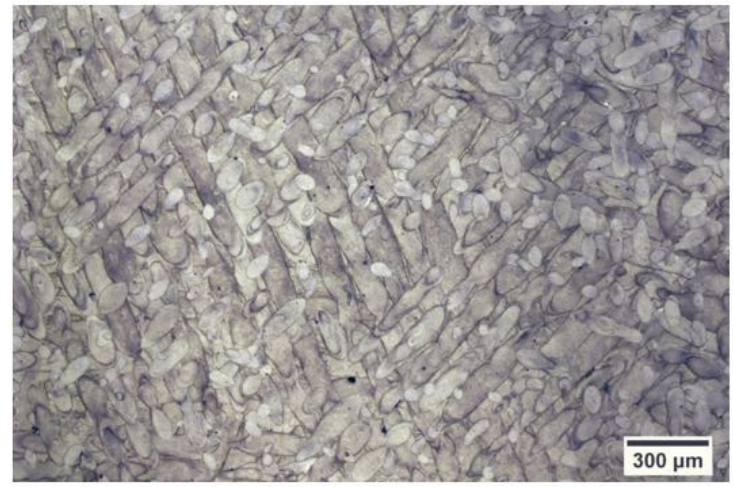

(a)

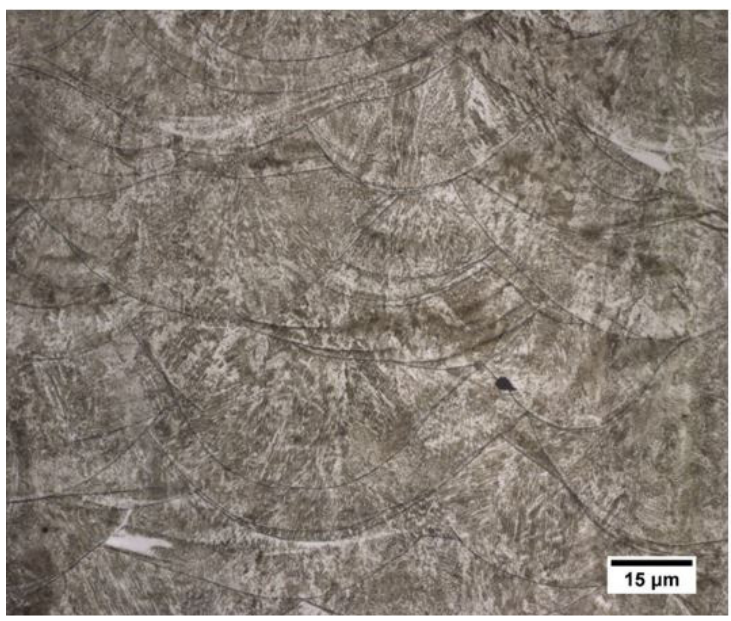

(b)

Figure 13. Micrography obtained by optical micrography of the maraging 300 steel produced by additive manufacturing ${ }^{67}$ : a) top view, etched with nital $2 \%$, b) side view, after two etchings: nital $2 \%$ and automatic polishing with the solution: $10 \mathrm{~mL}$ colloidal silica $+2 \mathrm{~mL}$ distilled water $+0.2 \mathrm{~g}$ ammonium persulfate.

to accumulate rotational mechanical energy, whose capacity depends on the values of the strength/density ratio. These devices have applications in hybrid vehicles due to its long-life cycle if compared to the lithium-ion batteries ${ }^{68,69}$.

In short, after 60 years of its existence, there are still several knowledge gaps related to maraging steels. In the area of mechanical working ${ }^{70,71}$, the lack of results on hot working processing maps in the 900 to $1300{ }^{\circ} \mathrm{C}$ temperature range is notorious for ultra-high-strength maraging steels 400 and 450 . There are few studies on oxidation, especially on the role of molybdenum. There is a lack also of a larger number of corrosion studies in liquid and gaseous environments. In the area of surface treatments, there are little comparative studies between several types of maraging steels, involving different nitriding processes. The new and more prominent experimental techniques, associated with mathematical modeling and artificial intelligence using neural networks and machine learning apart from other optimization methodologies, may contribute substantially to fill the mentioned gaps. This complementary knowledge 
positively should contribute to the broadening of the use of this class of steels.

Finally, it should be pointed out that the Fe-13Ni-15Co-10 Mo-Ti maraging steel family still presents an excellent potential for improvement and to obtain strength levels with YS over $3000 \mathrm{MPa}$. For instance, the molybdenum and titanium levels in this class of steels can be further optimized. Despite maybe seem contradictory at first glance, the development of maraging steels with a YS of $3 \mathrm{GPa}$ after aging may allow some sacrifice to its strength in favor of toughness through overaging and partial and controlled reversion of the martensite into austenite.

\section{Acknowledgments}

The authors are grateful to $\mathrm{CNPq}$ (Brazil) and CAPES (Brazil) for the scholarships and to Finep (Brazil) for supporting this project.

\section{References}

1. Mercier F, Hijikata T, Burrai V. Steel market developments: Q2 2020 [Internet]. Paris: OCDE Secretariat; 2020. 50 p. [cited 2020 Oct 4]. Available from: https://www.oecd.org/ officialdocuments/publicdisplaydocumentpdf/?cote=DSTI/ $\mathrm{SC}(2020) 1 /$ FINAL\&docLanguage $=$ En

2. Hall AM. High-strength steel perspectives. In: Tripartite Technical Cooperation Program, editor. Problems in load-carrying applications of high-strength steels. Columbus: Defense Metals Information Center; 1964. p. 1-13.

3. Frenkel J. Zur Theorie der Elastizitätsgrenze und der Festigkeit kristallinischer Körper. Z Phys. 1926;37(7-8):572-609. In german.

4. Orowan E. Fracture and strength of solids. Rep Prog Phys. 1949;12(1):185-232.

5. Schatt W. Einführung in die Werkstoffwissenschaft. Heidelberg: Dr. Alfred Hüthig Verlag; 1987. Auflage; p. 339-41. In german.

6. Meyers MA, Chawla KK. Mechanical behavior of materials. New Jersey: Prentice-Hall; 1998. p. 50-2.

7. Brenner SS. Tensile strength of whiskers. J Appl Phys. 1956;27(12):1484-91.

8. Rogne BRS, Thaulow C. Strengthening mechanisms of iron micropillars. Philos Mag. 2015;95(16-18):1814-28.

9. American Society for Testing \& Materials - ASTM. ASTM A228/A228M-18: standard specification for steel wire, music spring quality. West Conshohocken: ASTM; 2018. p. 1-5.

10. Li Y, Raabe D, Herbig M, Choi PP, Goto S, Kostka A, et al. Segregation stabilizes nanocrystalline bulk steel with near theoretical strength. Phys Rev Lett. 2014;113(10):106104.

11. Bargek HJ, Schulze G. Werkstoffkunde. Hannover: Hermann Schroedel Verlag KG; 1978. p. 131-3.

12. Hornbogen E, Rittner K. Development of thermo-mechanical treatments of a maraging steel for yield strengths above $3 \mathrm{GPa}$. Steel Res. 1987;58(4):172-7.

13. Yeo RBG, Miller O. A history of nickel from meteorites to maraging. In: Smith CS, editor. The Centennial Symposium on the History of Metallurgy; 1965; Cleveland, Ohio. Proceedings. New York: Gordon and Breach Science Publishers; 1965. p. 467-500.

14. Carvalho WP, Rios DC, Conceição H, Zucolotto ME, D’Orazio M. O meteorito Bendegó: história, mineralogia e classificação química. Rev Bras Geocienc. 2011;41(1):141-56.

15. Bieber CG. Nickel alloy. United States patent 3.093.518. 1963 June 11. Application Sept. 11, 1959.

16. Bieber CG. Progress with $25 \%$ nickel steels for high strength applications. Metal Progress. 1960;78(5):99-100.
17. Decker RF, Eash JT, Goldman AJ. 18\% nickel maraging steel. Trans ASM. 1962;55:58-76.

18. Zhou T, Faleskog J, Babu RP, Odqvist J, Yu H, Hedström P. Exploring the relationship between the microstructure and strength of fresh and tempered martensite in a maraging stainless steel Fe-15Cr-5Ni. Mater Sci Eng A. 2019;745:420-8.

19. Feitosa ALM. Efeito da laminação a frio na reversão parcial da martensita em austenita durante tratamento térmico de envelhecimento de aço maraging 350 [dissertation]. São Paulo: Polytechnic School of University of São Paulo; 2020.

20. Carvalho LG, Andrade MS, Plaut RL, Souza FM, Padilha AF. A dilatometric study of the phase transformations in 300 and 350 maraging steels during continuous heating rates. Mater Res. 2013;16(4):740-4.

21. Floreen S. The physical metallurgy of maraging steels. Metall Rev. 1968;13(1):115-28.

22. Rao MN. Progress in understanding the metallurgy of $18 \%$ nickel maraging steels. Int J Mater Res. 2006;97(11):1594-607.

23. Wang W, Yan W, Duan Q, Shan Y, Zhang Z, Yang K. Study on fatigue property of a new $2.8 \mathrm{GPa}$ grade maraging steel. Mater Sci Eng A. 2010;527(13-14):3057-63.

24. Menzel J, Klaar H-J. Systematische Untersuchungen am martensitaushärtenden Stahl X 2 NiCoMo 1315 10. Steel Res. 1990;61(1):30-8.

25. Vicente AA, Brandi SD, Padilha AF. Efeito do teor de molibdênio nas curvas de endurecimento por precipitação e na resistência à oxidação a altas temperaturas de aços maraging de ultra alta resistência mecânica. Tecnol Metal Mater Min. 2015;12(3):17987.

26. He Y, Yang K, Qu W, Kong F, Su G. Strengthening and toughening of a 2800-MPa grade maraging steel. Mater Lett. 2002;56(5):763-9.

27. He Y, Yang K, Sha W. Transmission electron microscopy of new high-strength grade maraging steels. Microsc Anal. 2007;21(2):5-7.

28. Sun L, Simm TH, Martin TL, McAdam S, Galvin DR, Perkins $\mathrm{KM}$, et al. A novel ultra-high strength maraging steel with balanced ductility and creep resistance achieved by nanoscale $\beta$-NiAl and Laves phase precipitates. Acta Mater. 2018;149:285301.

29. Gehricke B, Schruff I. Trends in plastic mould steel applications. In: Tool Steels in the Next Century: 5th International Conference on Tooling; 1999; Leoben, Austria. Proceedings. Leoben: Montanuniversität Leoben; 1999. p. 83-90.

30. FAS: Federation of American Scientists. Engineering consideration for gas centrifuge. Washington: FAS; 2020 [cited 2020 July 27]. Available from: https://fas.org/issues/nonproliferationcounterproliferation/nuclear-fuel-cycle/uranium-enrichmentgas-centrifuge-technology/engineering-considerations-gascentrifuges/

31. Sha W, Guo Z. Maraging steels: modelling of microstructure, properties and applications. Oxford: Woodhead Publishing; 2009. Microstructure of maraging steels; p. 17-48.

32. Magnée A, Drapier JM, Dumont J, Coutsouradis D, Habraken L. Cobalt-containing high-strength steels. Brussels: Centre D'Information du Cobalt; 1974.

33. Peters DT, Cupp CR. The kinetics of ageing reactions in $18 \% \mathrm{Ni}$ maraging steels. Trans AIME. 1966;236:1420-9.

34. Schmidt M, Rohrbach K. Heat treatment of maraging steels. In: ASM International. Metals handbook. Materials Park: ASM International; 1991. p. 219-28.

35. Bourgeot J, Maitrepierre P, Manenc J, Thomas B. Hardening Fe-Ni-Mo and Fe-Ni-Co-Mo martensitic alloys by tempering. Paris: IRSID; 1971. (IRSID International Report; 116)

36. Banerjee BR, Hauser JJ, Capenos JM. Role of cobalt in the marage type alloy matrix. Met Sci J. 1968;2(1):76-80.

37. Hagiwara M, Kawabe Y. Strength and toughness of a cold rolled 13Ni-15Co-10Mo maraging steel. Trans ISIJ. 1981;21:422-8. 
38. Nakazawa K, Kawabe Y, Muneki S. Grain refinement of highstrength maraging steels through cyclic heat treatment. Mater Sci Eng. 1978;33(1):49-56.

39. Kawabe Y, Muneki S, Nakazawa K. Relationship of processing variables in thermomechanical treatment to strength, ductility and toughness of $280 \mathrm{kgf} / \mathrm{mm} 2$ grade maraging steel. Trans ISIJ. 1980;20:682-9.

40. Drapier JM, Viatour P, Magnee A, Coutsouradis D. Etude structurale de l'acier maraging, nuance 400. Cobalt. 1971;50:2931. In french.

41. Fukamachi M, Kawabe Y, Nakazawa K, Muneki S. Transmission electron microscopy studies of structural changes in $13 \mathrm{Ni}-$ $15 \mathrm{Co}-10 \mathrm{Mo}$ maraging steel as a result of aging. J Jpn Inst Met. 1983;47(3):237-42. http://dx.doi.org/10.2320/jinstmet1952.47.3 237.

42. Mandia R. Characterization of intermetallic phases in Fe-Mo and Fe-Ta binary alloy systems [dissertation]. Aachen: RheinischWestfälische Technische Hochschule; 2019.

43. Padial AGF. Caracterização microestrutural do aço maraging de grau 400 de resistência mecânica ultra-elevada [thesis]. São Paulo: Instituto de Pesquisas Energéticas e Nucleares; 2002.

44. Alves TJB, Nunes GCS, Tupan LFS, Sarvesuk PWC, Ivashita $\mathrm{FF}$, Oliveira CAS, et al. Aging induced transformations of maraging-400 alloys. Metall Mater Trans, A Phys Metall Mater Sci. 2018;49(8):3441-9.

45. Crimmins PP. Evaluation of high-nickel maraging steels for application in large booster motor fabrication. In: Anderson RE, Crimmins PP, editors. Third maraging project review. Ohio: Air Force Materials Laboratory; 1963. p. 96-183. (Tech. Doc. Rept.; RTD-TDR 63-4048).

46. Dienst W. Hoch-Temperatur-Werkstoffe. Karlsruhe: Werkstofftechnische Verlagsgesselschaft m.b.H; 1979. p. 72-89.

47. Laque FL, Copson HR. Corrosion resistance of metals and alloys. New York: Reinhold Publishing Corporation; 1963.

48. Greyling CJ, Kotzé IA, Viljoen PE. The kinetics of oxide film growth on maraging steel as described by space-charge effects. Surf Interface Anal. 1990;16(1-12):293-8.

49. Brophy JH, Rose RM, Wulff J. Ciência dos materiais. Rio de Janeiro: Livros Técnicos e Científicos Editora Ltda; 1972. Oxidação; p. 125-35. (vol. 2: Propriedades termodinâmicas).

50. Friák M, Schindlmayr A, Scheffler M. Ab initio of the halfmetal to metal transition in strained magnetite. New J Phys. 2007;9(1):1-15.

51. Pfistermeister M, Kraff H, Coester E. Process for the formation of an anticorrosive, oxide layer on maraging steel. United States patent 4.141.759. 1979 Feb. 27.

52. Rezek J, Klein IE, Yahalom J. Structure and corrosion resistance of oxides grown on maraging steel in steam at elevated temperatures. Appl Surf Sci. 1997;108(1):159-65.

53. Floreen S. Maraging steels. In: ASM International. Metals handbook. Ohio: ASM; 1978. p. 445-52. (vol. 1: Properties and selection; Irons and steels).

54. Poornima T, Jagannatha N, Shetty AN. Studies on corrosion of annealed and aged $18 \mathrm{Ni} 250$ grade maraging steel in sulphuric acid medium. Port Electrochem Acta. 2010;28(3):173-88.

55. Poornima T, Nayak J, Shetty AN. Effect of 4-(N,N-diethylamino) benzaldehyde thiosemicarbazone on the corrosion of aged $18 \mathrm{Ni}$ 250 grade maraging steel in phosphoric acid solution. Corros Sci. 2011;53(11):3688-96.
56. Shetty K, Kumar S, Rao PR. Effect of ion nitriding on the microstructure and properties of maraging steel (250 Grade). Surf Coat Tech. 2009;203(10-11):1530-6. http://dx.doi.org/10.1016/j. surfcoat.2008.11.034.

57. Fernández de Ara J, Almandoz E, Palacio JF, Fuentes GG, Rodríguez RJ, García JA. Influence of temperature in arcactivated plasma nitriding of maraging steel in solution annealed and aged conditions. Surf Coat Tech. 2014;258:754-62.

58. Reis AG, Reis DAP, Abdalla AJ, Otubo J, Couto AA, Piorino F No. Hot tensile behavior and fracture characteristics of a plasma nitrided maraging 300 steel. Mater Sci Forum. 2017;899:43641.

59. Plaut RL, Herrera C, Escriba DM, Rios PR, Padilha AF. A short review on wrought austenitic stainless steels at high temperatures: processing, microstructure, properties and performance. Mater Res. 2007;10(4):453-60.

60. Azevedo CRF, Pereira HB, Wolynec S, Padilha AF. An overview of the recurrent failures of duplex stainless steels. Eng Fail Anal. 2019;97:161-88

61. Silva ALVC, Mei PR. Processos especiais de refino e obtenção de aços e ligas especiais. In: Silva ALVC, Mei PR, editors. Aços e ligas especiais. São Paulo: Edgard Blücher; 2008. p. 532-60.

62. Gibson I, Rosen D, Stucker B. Additive manufacturing technologies. New York: Springer; 2015.

63. Debroy T, Wei HL, Zuback JS, Mukherjee T, Elmer JW, Milewski JO, et al. Additive manufacturing of metallic components: process, structure and properties. Prog Mater Sci. 2018;92:112-224.

64. Turk C, Zunko H, Aumayr C, Leitner H, Kapp M. Advances in maraging steel for additive manufacturing. Berg Hüttenmännische Monatshefte. 2019;164(4):112-6.

65. Conde FF, Escobar JD, Oliveira JP, Jardini AL, Bose Filho WW, Avila JA. Austenite reversion kinetics and stability during tempering of an additively manufactured maraging 300 steel. Additive Manufacturing. 2019;29:100804. http://dx.doi. org/10.1016/j.addma.2019.100804.

66. Haghdadi N, Laleh M, Moyle M, Primig S. Additive manufacturing of steels: a review of achievements and challenges. J Mater Sci. 2020;56:64-107.

67. Feitosa ALM. Caracterização microestrutural e análise de textura cristalográfica do aço maraging 300 produzido por manufatura aditiva [undergraduate thesis]. Fortaleza: Departamento de Engenharia Metalúrgica e de Materiais, Universidade Federal do Ceará; 2017.

68. Purohit P, Ramachandran M. Selection of flywheel material using multicriteria decision making fuzzy topics. Indian J Sci Technol. 2015;8(33):1-5.

69. Itani K, Bernardinis A, Khatir Z, Jammal A. Comparative analysis of two hybrid energy storage systems used in a two front wheel driven electric vehicle during extreme start-up and regenerative braking operations. Energy Convers Manage. 2017;144:69-87.

70. Chakravarthi KVA, Koundinya N, Narayana Murty SVS, Rao BN. Microstructure, properties and hot workability of M300 grade maraging steel. Defence Technology. 2018;14(1):51-8.

71. Chakravarthi KVA, Koundinya N, Narayana Murty SVS, Rao BN. Microstructural evolution and constitutive relationship of M350 grade maraging steel during hot deformation. J Mater Eng Perform. 2017;26(3):1175-85. 